\title{
Hogyan befolyásolja a kultúra az egészséget és a jóllétet? III. rész: Környezet, kultúra és egészség
}

How does culture affect health and well-being?

Part III: Environment, culture and health

A három részből álló cikksorozat további részei: "I. rész: Az egészség kulturális beágyazottsága”, "Il. rész: Táplálkozás, kultúra és egészség"

Szerző: $\quad$ Csizmadia Péter $\square$

Emberi Eröforrások Minisztériuma

Beküldve: 2017.06.22.

doi: 10.24365/ef.v58i2.160

Kulcsszavak: környezet, egészség, kultúra, jóllét

Keywords: environment, health, culture, well-being

\section{KULTURÁLIS KONCEPCIÓK A KÖRNYEZETRŐL}

A fizikai környezet bizonyos tényezői, mint a levegő, a víz, a napsugárzás, a talaj közvetlenül befolyásolják az egészséget. A természetről, ezen belül az ember természetben betöltött szerepéről kialakított elképzelések társadalmilag és kulturálisan nagymértékben meghatározottak. Egy folyó egyrészről kellemes környezetet biztosíthat egy beszélgetéshez, vagy testedzéshez, mások imádkozásra vagy elmélkedésre alkalmas szent helyként tekinthetnek rá, lehet technikai fejlesztés színtere, személyes emlékeket idéző hely, csoport vagy egyéni identitás, kulturális örökség megtestesítője, egyeseknek csak alkalmas szemétlerakó, míg másoknak természetes szépség, amit meg kell őrizni az emberi tevékenységtől vagy egyszerűen csak táplálék beszerzésének a színtere.

Kontextustól függően a környezetről való beszédben kölcsönözhetünk metaforákat a közgazdaságtanból (természeti tőke), a várostervezéstől (zöld területek), a biológiától (ökoszisztéma), vagy a mitológiából (Föld Anya).

Egyéb kapcsolatainkhoz hasonlóan az ember és a környezete közötti viszony is képlékeny, olyan tényezők által befolyásolt, mint az oktatás, a gazdaság, az urbanizáció, az iparosítás, a migráció, a társadalmi egyenlőtlenségek, az erőforrások kimerülése.

Annak a megértése, hogy a környezetről alkotott kulturális elméletek hogyan kapcsolódnak az egészséghez és a jólléthez, soha nem volt fontosabb. Míg a globális narratívák a környezetvédelemről elsősorban a fenntartható fejlődésre és az erőforrásokkal való hatékony gazdálkodásra összpontosítanak, számos kultúrában megfigyelhetőek különböző modellek, amelyek az ember és környezetének egymásrautaltságát hangsúlyozzák. A legtöbb természeti nép közvetlen ok-okozati összefüggést lát a jóllét és a Föld állapota között. A gyógyítás folyamata esetükben közvetlenül a természethez való fordulást jelenti fizikai és spirituális segítségért, egyfajta morá- 
lis szerződést az ember és környezete között, amelyek mélyek és hosszú ideig tartók.

Annak ellenére, hogy manapság az úgynevezett kulturális ökoszisztéma szolgáltatások már elismerésre kerültek a Millenniumi Ökoszisztéma Becslés által definiálva, mely szerint a társadalmi jóllét pillérei a természet biztosította bázison nyugszanak, ezek a kulturálisan megalapozott stratégiák az egészség és a természeti környezet kapcsolatának elősegítésére, még feltáratlannak számítanak. ${ }^{1,2}$

\section{A KÖZÖSSÉGEK TÁMOGATÁSA ZÖLD ÉS KÉK TE- RÜLETEKHEZ VALÓ HOZZÁFÉRÉSBEN}

Az egészség és a környezet közti összefüggések kulturális megjelenítése az emberiség történelmének legkorábbi időszakáig visszavezethető. A Paradicsomról alkotott elképzelések számos esetben öszszekapcsolódnak a kert képzetével, és a gyógyítás tiszteletére emelt templomokat gyakran tengerre néző hegytetőkön helyezték el. Manapság számos bizonyítékon alapuló kutatás támasztja alá, hogy a természetben eltöltött idő kedvezően befolyásolja az emberek egészségét. Azok az emberek, akik kevés időt töltenek természetes környezetben, kimutathatóan nagyobb eséllyel szenvednek mentális megbetegedésben. A szabad levegőn eltöltött idő hiánya összefüggést mutat az alacsony szintű fizikai aktivitással, az egészségtelen táplálkozással és a nem fertőző megbetegedések éles emelkedésével. Ennek megfelelően számos döntéshozó kiemeli a zöld területek (városi parkok, erdők, egyéb természetes területek) az ún. kék területek (vízpartok, vízi utak) és az egészség közti kapcsolatot. A kék és a zöld területek egészségben és jóllétben betöltött fontossága kifejezésre került a WHO Egészséges Városok Hálózatának kialakításában, az Európai Táj Egyezmény elfogadásában, amelyet Magyarországon a 2007. évi CXI. törvény hirdetett ki, az Natura2000 hálózat Európai Unió által történt létrehozásában, illetve számos, a városi egészségre törekvő interszektoriális programban. Ez a trend befolyásolta az egészségügyi ellátást. Több kórházat, mentális egészséggel foglalkozó intézményt, valamint idősek számára épült ellátó otthon alakítottak ki úgy, hogy a friss levegő és a napfény terápiás céllal kiemelésre került, hangsúlyt helyeztek a fák kö- zelségére és a szép kilátás kialakítására.

A természetes táj, mint a társadalmi és kulturális örökség megtestesülése szintén a folyamatosság érzetét adja, részét képezi az egészséges identitás kialakulásának, hozzájárul az egészség, mint identitásképző hangsúlyozásához, amelynek protektív (védő) szerepe lehet az egészégre és a jóllétre. Az Északkelet-Angliában egykori nehézipari, deprivált (súlyosan hátrányos helyzetû) tengerparti területeken lezajlott egészségegyenlőtlenségeket vizsgáló kutatások azt sugallják, hogy az erős kulturális-történeti kapcsolatok a közösség tagjai és a környezetük között részben magyarázzák a vártnál jobb egészségeredményeket. ${ }^{3}$

Ráadásul a zöld és kék területek olyan közösségi tereket biztosíthatnak, amelyek támogatják új kapcsolatok kialakítását. Néhány kutatás úgy érvel, hogy az erős érzelmi kötődés kialakulása fontos szerepet játszhat a migránsok integrációjában a városias területeken.

Nem meglepő, hogy a megszokott környezet elvesztése vagy gyors átalakítása vagy átalakulása közvetlenül hathat a jóllétre és az elégedettségre. Egy kutatás úgy találta, hogy a közösségek nemcsak azért tiltakoznak az új technológiák ellen, mert félnek például a szennyezés azonnali hatásaitól, hanem mert tartanak a környezet megváltozásától vagy károsodásától. ${ }^{4}$

Ugyanez igaz olyan közösségekre, amelyek folyamatos zajterhelésnek vannak kitéve és a természetes állatvilág súlyos károsodása fenyeget, pl. a szélparkok miatt. Az a döntés, hogy a veszélyesebb nukleáris erőmúveket nagy kiterjedésű szélparkokkal helyettesítsék, szintén káros lehet az ott élő közösségek számára, hiszen a lakókörnyezetükben radikális változásokat okozhat a szélerőmú telepítése. A dicséretes erőfeszítések, az energiaforrások környezetbarát formáinak népszerűsítése elhibázottá válhat, ha a helyi kulturális értékeket nem veszik figyelembe.

A természetes környezet védelme vagy zöld és kék területek kialakítása önmagában nem elég. Fenn kell tartani a kulturális érzékenységet, amely törekszik a hozzáférés növelésére, a közbiztonság, az új táplálkozási és testedzési szokások kialakítására. Változatos, innovatív kezdeményezések szükségesek, amelyek támogatják a kapcsolatok kultúráját, és az elkötelezettség új modelljeit kínálják, amelyek 
megvalósíthatók és megismételhetők Ezek együtt támogathatják az egészségbarát tervezést és döntéshozatalt.

\section{AZ ESÉLYEGYENLŐSÉG ÉS A HOZZÁFÉRÉS BIZTO- SÍTÁSA}

Az egészségbarát természetes területek nem egyenlő módon hozzáférhetők mindenki számára. A 19. században a döntéshozók felismerték a természetes környezet kulturális és egészségben betöltött kiemelkedő jelentőségét. Ez számos közpark és természetvédelmi terület létrehozásához vezetett Európában és az Egyesült Államokban. ${ }^{5}$ Emellett azonban a kulturális előítéletek miatt egyes őslakos közösségeket, gondoljunk csak az észak-amerikai indiánokra, kiszakítottak természetes környezetükből, mert az életmódjukat és a környezettel való kapcsolatukat helytelennek, elavultnak ítélték. Míg a kiváltságos társadalmi csoportok számára lehetővé tették ezen területek művelés alá vonását, a bennszülötteket kitiltották onnan, ahol a közösségeik számára évezredeken át biztosított volt a rájuk jellemző életmód gyakorlása.

Ma a WHO Európai régiójában, a vízparti területek széleskörűen elismert egészségre gyakorolt kedvező hatása ellenére, az adott ország kulturális szokásai miatt számos vízparton élő közösség kirekesztve érzi magát vagy képtelen kihasználni az egészségbarát kék területeket. Ez származhat a megfelelő rekreációra fordítható szabadidő hiányából, vagy abból az érzésből, hogy ezek a területek csak a turisták kényelmét szolgálják. Egy Glasgowban folytatott kutatás szerint a deprivált népesség úgy érzékelte, hogy a lakókörnyezetükben lévő parkosított területeket nem vehetik igénybe.

Hasonló jelenség volt megfigyelhető Koppenhágában. 2014-ben Koppenhága lett Európa Zöld Fővárosa. Az ott élők 96\%-a él 15 percnyi sétán belül valamilyen parkhoz vagy zöld területhez. Itt található a világ legjobban kiépített kerékpárút hálózata. Ráadásul Dániában a legmagasabb a magukat boldognak vallók aránya, komoly kormányzati támogatást kap a fizikailag aktív életmód és viszonylag alacsony szinten vannak a városban az életmóddal összefüggő megbetegedések. Koppenhága sikerei az egészség és környezetpolitika terén összekapcso- lódnak azzal a kultúrával, amelyben az egészséges és fenntartható életmód nagyra értékelt. Azonban egy friss antropológiai kutatás szerint ezek a normák és értékek nem univerzálisak a város lakói között. Az alacsony jövedelemmel rendelkező közösségekben a nők bizonyos egészségbarát tevékenységeket úgy értékelnek, hogy az a maguk számára nehezen elérhető, keveset kamatoztathatnak a sokak által ünnepelt városi zöld területekből. A lecke egyértelmú: a döntéshozóknak törekedni kell társadalmi kirekesztettség aktív csökkentésére, hisz a társadalmi példából is látszik, az egyenlőtlenségek tartósan fennmaradhatnak még az egyenlőségre törekvő társadalmakban is. ${ }^{6} \mathrm{Az}$ egészségbarát tényezőket gyengítheti vagy károsíthatja az emberi tevékenység még a könnyen hozzáférhető természetes vagy zöld és kék területek esetén is. A szennyezett levegő, víz és talaj, a sugárzás magas szintje, az egyre gyakoribb szélsőséges időjárás, az éghajlatváltozás számos közösség számára napi realitást jelent.

A döntéshozóknak sokszínű közösségek számára kell megoldási javaslatokkal rendelkezniük, különösen a marginalizáltak számára, annak a jobb megértése érdekében, hogy a környezet kulturális normák és értékek által meghatározott felfogása hogyan befolyásolja a magatartást pozitív és negatív irányban egyaránt. Különböző módszereket alkalmazó kutatások szükségesek annak az azonosításához, hogy miért történik meg, hogy az egészséghez és a fenntarthatósághoz kapcsolódó szakpolitikák sikertelenek bizonyos társadalmi csoportok esetében, és hogyan lehetséges adaptív és integratív megoldásokat kidolgozni.

\section{AJÁNLÁSOK}

1. Vizsgálják meg, hogy a kulturális tényezők hogyan befolyásolják az észlelést és a környezeti szempontok figyelembe vételét, valamint azt, hogy az erős kulturális kapcsolatok az emberek és az általuk értékesnek tekintett területek között hogyan javítják az egészséget és a jóllétet.

2. Dolgozzanak ki olyan módszertant, amely lehetővé teszi a kulturális értékek integrációját az egészséghez és környezethez kapcsolódó döntéshozatalban. 
3. Azonosítsanak és használjanak olyan kulturális gyakorlatokat, amelyek segítik a zöld és kék területek pozitív szerepének elismerését.
4. Csökkentsék az egyenlőtlenségeket, amelyek akadályoznak bizonyos közösségeket a zöld és a kék területekhez és azok pozitív hatásaihoz való hozzáférésben.

\section{HIVATKOZÁSOK}

\footnotetext{
${ }^{1}$ Az ökoszisztéma szolgáltatásokra számos definíció létezik. Egyes szerzők az ökoszisztémák azon részeit, állapotait, folyamatait nevezik ökoszisztéma szolgáltatásnak, amelyek az élet fenntartásához szükségesek, mások azokat a hasznokat tartják ökoszisztéma szolgáltatásnak, amelyeket az emberek az ökoszisztémákból nyernek.

${ }^{2}$ A Millenniumi Ökoszisztéma Becslésről bővebben: http://ec.europa.eu/environment/pubs/pdf/factsheets/Ecosystems\%20goods\%20and\%20Services/Ecosystem HU.pdf. (Elérve: 2017. június 19.)

${ }^{3}$ Cairns-Nagi JM, Bambra C. Defying the odds: a mixed-methods study of health resilience in deprived areas of England. Soc Sci Med. 2013;91(0):229-37. doi:10.1016/j.socscimed.2013.03.014.

${ }^{4}$ Kovats S, Depledge MH, Haines A, Fleming L, Wilkinson P, Shonkoff SB, Scovronick N. The health implications of fracking. Lancet 2014;383(9919):757-8. doi:10.1016 S0140-6736(13)62158-3.

${ }^{5}$ Csizmadia, Péter. Az épített környezet hatása az egészségmagatartásra. Egészségfejlesztés. Évf. 57, Szám 2 (2016). 8588.

${ }^{6}$ Thomas F. The role of natural environments within women's everyday health and wellbeing in Copenhagen, Denmark. Health Place 2015;35:187-95. doi:10.1016/j.healthplace.2014.11.005.
} 